Abstracta Iranica Abstracta Iranica

Revue bibliographique pour le domaine irano-aryen

Volume 27 | 2006

Comptes rendus des publications de 2004

\title{
The Caspian. Politics, Energy and Security. Londres, Routledge Curzon, 2004, 405 p.
}

\section{Bernard Hourcade}

\section{(2) OpenEdition \\ 12 Journals}

Édition électronique

URL : http://journals.openedition.org/abstractairanica/6596

DOI : $10.4000 /$ abstractairanica.6596

ISSN : 1961-960X

\section{Éditeur :}

CNRS (UMR 7528 Mondes iraniens et indiens), Éditions de l'IFRI

\section{Édition imprimée}

Date de publication : 15 mai 2006

ISSN : 0240-8910

\section{Référence électronique}

Bernard Hourcade, «The Caspian. Politics, Energy and Security. Londres, Routledge Curzon, 2004 405 p. », Abstracta Iranica [En ligne], Volume 27 | 2006, document 351, mis en ligne le 02 janvier 2007 , consulté le 25 septembre 2020. URL : http://journals.openedition.org/abstractairanica/6596 ; DOI : https://doi.org/10.4000/abstractairanica.6596

Ce document a été généré automatiquement le 25 septembre 2020.

Tous droits réservés 


\title{
The Caspian. Politics, Energy and Security. Londres, Routledge Curzon, 2004, 405 p.
}

\author{
Bernard Hourcade
}

1 Cet ouvrage est le meilleur qui ait été publié sur la situation et les enjeux notamment énergétiques de la région caspienne. Les 21 articles, bien documentés et illustrés traitent du droit, de la question des oléoducs, des problèmes économiques et sociaux, des questions régionales et enfin de sécurité, ce qui permet d'avoir un tableau de tous les aspects à la fois pétrolier et socio-politiques de cette région qui passe du soviétisme à l'intégration internationale dans un contexte très spécifique. La lecture de l'ouvrage est facilitée par un bon index des noms propres et des notions. Ces contributions sont mises en perspective et très bien synthétisées par Sh. Akiner qui souligne combien l'intégration internationale de ces régions enclavées est maintenant en cours via la pétrole, mais réitère, comme la plupart des auteurs, ses craintes que ces nouveaux pays pétroliers de la région caspienne ne soient confrontés aux mêmes difficiles expériences que les autres pétro-États.

\section{INDEX}

Thèmes : 13.1. Iran 
AUTEURS

BERNARD HOURCADE

CNRS - Paris 